\title{
ФОТОАФИННЫЕ ЗОНДЫ ДЛЯ ИЗУЧЕНИЯ АЛЛОСТЕРИЧЕСКОЙ РЕГУЛЯЦИИ ALOX15
}

\section{В.О. Конотопов, А.Б. Голованов, И.В. Иванов, А.М. Журавлев}

Институт Тонких Химических Технологий им. М.В. Ломоносова, ФГБОУВО МИРЭА Российский технологический университет, 119571, Россия, Москва, пр. Вернадского, 86.

DOI: 10.19163/MedChemRussia2021-2021-346

E-mail: alekszhur95@yandex.ru

Липоксигеназы (ALOXs) и их продукты, оксилипины, участвуют в процессах созревания и дифференцировки клеток, а также в патогенезе воспалительных, гиперпролиферативных, неврологических заболеваний и др. Арахидонат-15-липоксигиназа (ALOX15) - представитель ферментов семейства диоксигеназ, содержит негемовое железо в активном центре и катализирует региоселективную стереоспецифическую реакцию перекисного окисления полиненасыщенных жирных кислот до соответствующих гидропероксипроизводных. В последние годы, исследования в области процессов катализа с участием ALOX обнаружили явление аллостерический регуляции активности ALOX15, что требует использование новых подходов для установления структуры и положения центров аллостерической регуляции данной группы ферментов.

На данный момент изучения механизма действия ALOX15 существует гипотеза, которая постулирует об аллостерической регуляции фермента за счет образования переходного димера фермента. При этом один из мономеров является каталитическим центром, а второй мономер выступает в качестве аллостерического центра, с которым может связаться эффектор (активатор или ингибитор), тем самым влияя на ферментативную активность по отношению к субстрату [1, 2]. С целью получения экспериментального подтверждения этого механизма был проведен синтез фотоаффинных лигандов на основе аллостерического эффектора ALOX15 ((Е)-1-(7-бензилиден-3-фенил-3,3а,4,5,6,7гексагидро-2Н-индазол-2-ил)-2-(4-метилпиперазин -1-ил)этан-1-он [3]) и аналога ингибитора RS7 - производного (E)-3-(2-(окт-1-ин-1-ил)фенил)акриловой кислоты, который связывается в активном центре фермента и может быть использован в качестве контроля. Активация полученных зондов интенсивным УФ-излучением приведёт к ковалентной сшивке с расположенными в центре связывания аминокислотными остатками ALOX15. Анализ фрагментов ALOX15 после протеолитического расщепления позволит установить точное положение аллостерического центра в структуре фермента.

Работа выполнена при финансовой поддержке гранта РФФИ, проект № 19-54-12002.

\section{Литература}

[1] I. Ivanov et al, Proteins. 2011, 80, 703-712

[2] I. Ivanov et al, Int. J. Mol. Sci. 2021, 22, 3285

[3] H. Meng et al, J. Med. Chem. 2016, 59, 4202-4209

$$
-346-
$$

